\title{
Runoff prediction from sagebrush rangelands using water erosion prediction project (WEPP) technology
}

\author{
BRADFORD P. WILCOX, MINA SBAA, WILBERT H. BLACKBURN, AND JAMES H. \\ MILLIGAN
}

\begin{abstract}
Authors are hydrologist, Los Alamos National Lab, EES-15, MS J495, Los Alamos, N.M. 87545; graduate research assistant, Department of Civil Engineering, University of Idaho, Moscow, Ida. 83712; supervisory hydrologist, USDA-ARS, Northwest Watershed Research Center, 800 Park Boulevard, Plaza IV, Boise, Ida. 83712; professor, Department of Civil Engineering, University of Idaho, Moscow 83712. At the time of the study, the senior author was a hydrologist at the Northwest Watershed Research Center.
\end{abstract}

\begin{abstract}
Runoff prediction is an important component of any processbased soil erosion model. In this paper we evaluate the runoff prediction capabilities of a new soil erosion model, WEPP, on sagebrush rangelands. Particular attention was given to the parameter estimation techniques used in WEPP to predict infiltration. Runoff volume predicted by WEPP is based on the Green and Ampt infiltration equation. Predicted runoff was compared to observed runoff from 90 large plot rainfall simulation experiments on sagebrush rangelands. There was a poor correlation between predicted and observed runoff when the Green and Ampt parameters were estimated using the parameter estimation techniques. Runoff prediction was improved when parameters were determined from field measurements. Additional refinement of the Green and Ampt parameterization techniques is needed for continued improvement of WEPP.
\end{abstract}

The new soil erosion model, WEPP, (Water Erosion Prediction Process) (Lane and Nearing 1989) simulates the major processes that impact soil erosion by water, runoff being one of the more important ones. WEPP is a process-based model in that it has a theoretical framework and that the model parameters are directly measurable. Application of process-based hydrologic models as practical land management tools has been limited because of the difficulty of parameterizing them. Identification of parameter values requires either (1) elaborate field testing, which is expensive and time consuming, or (2) calibration to a measured runoff time series.

Model parameterization in WEPP has been simplified by the development of empirical relationships between the WEPP parameters and readily available soil and vegetation characteristics. This allows for easy parameterization and gives WEPP the potential to simulate the impact of vegetation change to rangeland water cycles. We emphasize that although the core equations in WEPP have a theoretical basis, the parameter estimation procedures are strictly empirical.

Wilcox et al. (1990) found that runoff from a small (1 ha) sagebrush watershed was poorly predicted by WEPP. In this study, we evaluate WEPP runoff prediction in more detail using rainfall simulation data. Particular attention was given to the parameter estima-

Authors gratefully acknowledge the efforts of Cliff Johnson and Mark Murdock, who coordinated the rainfall simulation experiments used in this study, and Don Brakensiek, who provided guidance and advice. Helpful reviews were given by Ken Renard, Jeff Stone, Walter Rawls, Mark Nearing, and 2 JRM reviewers. Preliminary work for this study was done by Ahmed Agdi.

Manuscript accepted 17 Nov. 1991. tion techniques used in runoff prediction. Predicted runoff was compared to observed runoff from rainfall simulation experiments conducted on or near the Reynolds Creek experimental watershed in southwestern Idaho. There was a poor correlation between predicted and observed runoff when the parameters were estimated from the empirical relationships. Results were improved when parameters were estimated from field measurements. Additional refinement of the parameter estimation techniques is needed for improved runoff prediction by WEPP.

\section{WEPP Infiltration Model Description}

\section{Green and Ampt Equation}

Runoff is predicted using a time-based infiltration approach. The amount of water that does not infiltrate is assumed to be runoff. The infiltration process is simulated with the Green and Ampt equation modified by Chu (1978) for unsteady rainfall. The utility of the Green and Ampt equation for predicting infiltration has been demonstrated by Mein and Larson (1971) and Smith and Parlange (1978), among others. Details of the procedure are described by Rawls et al. (1989b). Infiltration capacity is calculated by the Green and Ampt equation as

$$
f=K_{e}\left[1+\left(N_{s} / F\right)\right]
$$

where $\mathrm{f}$ is infiltration capacity $(\mathrm{mm} / \mathrm{hr}), \mathrm{K}_{\mathrm{e}}$ is effective hydraulic conductivity $(\mathrm{mm} / \mathrm{hr}), \mathrm{N}_{\mathrm{a}}$ is effective matric potential $(\mathrm{mm})$ and $\mathrm{F}$ is total infiltration (mm). $N_{s}$ and $K_{v}$ can be estimated in WEPP using parameter estimation techniques.

\section{Parameter Estimation}

$\mathrm{K}_{\mathrm{e}}$ is estimated in WEPP using a 2 step process. First saturated hydraulic conductivity, $K_{\mathbf{z}}$, is estimated using the following empirical relationship, which takes into account the effects of entrapped air, soil texture, organic matter, and cation exchange capacity (Rawls et al. 1989a).

$$
\mathrm{K}_{\mathrm{s}}=0.002 \frac{\left[\mathrm{P}_{d}(\mathrm{EAC})-\mathrm{SM}_{\mathrm{r}}\right]^{3}}{\left[1-\mathrm{P}_{d}(\mathrm{EAC})^{2}\right.}\left[\frac{\mathrm{BD}}{\mathrm{SM}_{\mathrm{r}}}\right]^{2} \quad \mathrm{CL}^{2}
$$

Where

$$
\begin{aligned}
\mathrm{EAC} & =\text { correction for entrapped air } \\
& =1.0-\left(3.8+0.00019(\mathrm{C})^{2}-0.337(\mathrm{~S})+0.126(\mathrm{CEC})(\mathrm{C})\right. \\
& +(\mathrm{OM})(\mathrm{S} / 200)^{2} / 100 \\
\mathrm{BD} & =\text { bulk density }\left(\mathrm{Mg} / \mathrm{m}^{3}\right) \\
\mathrm{CL} & =0.17+0.181(\mathrm{C})-0.00000069\left(\mathrm{~S}^{2}\right)\left(\mathrm{C}^{2}\right)-0.00000041\left(\mathrm{~S}^{2}\right)(100-\mathrm{S}-\mathrm{C})^{2} \\
& +0.000118\left(\mathrm{~S}^{2}\right)\left(\mathrm{BD}^{2}\right)+0.00069\left(\mathrm{C}^{2}\right)\left(\mathrm{BD}^{2}\right) \\
& +0.000049\left(\mathrm{~S}^{2}\right)(\mathrm{C})-0.000085\left(100-\mathrm{S}-\mathrm{C}^{2}\right)\left(\mathrm{C}^{2}\right) \\
\mathrm{S} \quad & =\% \text { sand } \\
\mathrm{C} & =\% \text { clay }
\end{aligned}
$$


$P_{e} \quad=$ effective soil porosity $\left(\mathrm{mm}^{3} / \mathrm{mm}^{3}\right)$

$\mathrm{OM}=$ organic matter (\%)

$\mathrm{SM}_{\mathbf{r}}=$ residual soil water content $\left(\mathrm{mm}^{3} / \mathrm{mm}^{3}\right)$

$K_{e}$, the effective conductivity, incorporates the effect of vegetation on hydraulic conductivity (Rawls et al. 1989a) as follows:

$\left.K_{e}=K_{s}\left\{C_{f}\left[B_{c} / A_{c}\right) C_{r}+M_{f}\left(1-\left(B_{c} / A_{c}\right)\right)\right]+\left(B_{o} / A_{o}\right) C_{r}+M_{f}\left(1-B_{0} / A_{0}\right)\right\}(5)$

$A_{c}=$ canopy area (\%)

$A_{0}=$ open area outside canopy $\left(100-A_{c}\right)(\%)$

$\mathrm{B}_{\mathrm{c}}=$ bare area under canopy (\%)

$B_{0}=$ bare area in open space (\%)

$C_{f}=$ canopy factor $=1+A\left(A_{0} / 100\right)$

$\mathbf{M}_{\mathbf{f}}=$ macro-porosity factor $=\exp (6.1-0.103 \mathrm{~S}-0.37 \mathrm{C})$

if $\mathrm{M}_{\mathrm{r}}<0.4$, then $\mathrm{M}_{\mathrm{f}}=0.4$

$$
C_{r}=\text { crust factor }=\frac{L}{\frac{L-Z_{c}}{S C}+\frac{Z_{c}}{b}}
$$

$L=$ depth to wetting front (mm)

$=147-\left(0.015 \mathrm{~S}^{2}\right)-3(\mathrm{C})(\mathrm{BD})$

if $\mathrm{L}<1$, then $\mathrm{L}=1$

$Z_{c}=$ crust thickness (assume $5 \mathrm{~mm}$ )

$\mathrm{SC}=$ correction factor for partial saturation of the subcrust soil (Brakensiek and Rawls, 1983)

$b=0.0099+0.0721\left(Z_{c}\right)+0.0000068\left(S^{2}\right)+0.000021\left(S^{2}\right)\left(Z_{c}\right)-$
$0.000315(S)\left(Z_{c}^{2}\right)$
Effective matric potential, $N_{*}$, was derived using the following relationship.

$$
N_{\mathrm{s}}=\left(1-\mathbf{S}_{\mathrm{e}}\right)\left(\mathbf{P}_{\mathrm{e}}\right)\left(\mathbf{S}_{\mathrm{f}}\right)
$$

Where

$S_{0}=$ effective saturation $\left(\mathrm{mm}^{3} / \mathrm{mm}^{3}\right)$

$S_{f}=$ average matric potential across the wetting front (mm)

$S_{f}$ was estimated using the following regression equation (Rawls and Brakensiek, 1985).

$$
\begin{aligned}
S_{f} & =\exp \left[6.5309-7.32561(P)+0.001583(C)^{2}+3.809479\left(P_{e}\right)^{2}\right. \\
& +0.000344(S)(C)-0.049837(S)\left(P_{e}\right)+0.001608(S)^{2}\left(P_{e}\right)^{2} \\
& +0.001602(C)\left(P_{e}\right)^{2}-0.0000136(S)^{2}(C)-0.003479(C)^{2}\left(P_{e}\right)^{2} \\
& \left.-0.000799(S)\left(P_{e}\right)\right]
\end{aligned}
$$

\section{Methods}

\section{Rainfall Simulation Experiments}

Runoff volume predicted by WEPP was compared to measured runoff volume from large plot ( 3.05 by $10.67 \mathrm{~m}$ ) rainfall simulation studies carried out on 6 sagebrush rangeland sites on or near the

(9) Reynolds Creek Experimental Watershed in southwestern Idaho (Johnson et al. 1984, Johnson and Blackburn 1989). Selected soil and vegetation characteristics are given in Table 1 . Johnson et al. (1984) conducted rainfall simulation studies to improve estimates of USLE parameters for sagebrush rangelands. The study con-

\begin{tabular}{|c|c|c|c|c|c|c|c|c|}
\hline TRT & $\mathbf{S}$ & C & OM & $\mathrm{CC}$ & GC & $\mathbf{M}_{\mathbf{f}}$ & $\mathrm{C}_{\mathrm{f}}$ & $\mathrm{C}_{\mathrm{r}}$ \\
\hline & & & & Nancy 87 & & & & \\
\hline & $(\%)$ & (\%) & $(\%)$ & (\%) & $(\%)$ & & & \\
\hline Grazed & 33 & 14 & 1.8 & 12 & 81 & 8.73 & 1.12 & 0.68 \\
\hline Clipped & 33 & 14 & 1.8 & 0 & 72 & 8.73 & 1.00 & 0.68 \\
\hline \multirow[t]{2}{*}{ Bare } & 33 & 14 & 1.8 & 0 & 49 & 8.73 & 1.00 & 0.68 \\
\hline & & & & Summit & & & & \\
\hline Grazed & 76 & 6 & 1.7 & 16 & 55 & 0.40 & 1.16 & 0.74 \\
\hline Clipped & 76 & 6 & 1.7 & 0 & 67 & 0.40 & 1.00 & 0.74 \\
\hline \multirow[t]{2}{*}{ Bare } & 76 & 6 & 1.7 & 0 & 9 & 0.40 & 1.00 & 0.74 \\
\hline & & & & Coyote Butte & & & & \\
\hline Grazed & 25 & 14 & 1.5 & 39 & 85 & 20.23 & 1.39 & 0.68 \\
\hline Clipped & 25 & 14 & 1.5 & 0 & 90 & 20.23 & 1.00 & 0.68 \\
\hline \multirow[t]{2}{*}{ Bare } & 25 & 14 & 1.5 & 0 & 54 & 20.23 & 1.00 & 0.68 \\
\hline & & & & Flats & & & & \\
\hline Ungrazed & 59 & 8 & 1.2 & 53 & 88 & 0.76 & 1.53 & 0.72 \\
\hline Grazed & 61 & 11 & 2.2 & 43 & 82 & 0.55 & 1.43 & 0.67 \\
\hline \multirow[t]{2}{*}{ Clipped } & 53 & 9 & 2.2 & 0 & 75 & 1.36 & 1.00 & 0.71 \\
\hline & & & & Lower Sheep & & & & \\
\hline Ungrazed & 35 & 17 & 4.6 & 64 & 92 & 6.46 & 1.64 & 0.62 \\
\hline Grazed & 35 & 17 & 6.3 & 53 & 89 & 6.46 & 1.53 & 0.64 \\
\hline \multirow[t]{2}{*}{ Clipped } & 32 & 21 & 5.1 & 2 & 94 & 7.59 & 1.02 & 0.46 \\
\hline & & & & Nancy82 & & & & \\
\hline Ungrazed & 43 & 14 & 3.2 & 47 & 88 & 3.17 & 1.47 & 0.68 \\
\hline Grazed & 44 & 11 & 2.7 & 46 & 90 & 3.19 & 1.46 & 0.70 \\
\hline Clipped & 41 & 16 & 2.3 & 0 & 84 & 3.61 & 1.00 & 0.66 \\
\hline
\end{tabular}
ducted by Johnson and Blackburn (1989) was designed for validation of the WEPP model.

Three sites from Johnson et al. (1984) were evaluated: Flats, Lower Sheep, and Nancy82. At each site, 3 different treatments

Table 1. Soil and vegetation cover characteristics at each site.

OM-Organic matter

CC-Canopy cover

GC-Ground cover

C-\% clay

$\mathbf{M}_{\boldsymbol{r}}-$ Macroporosity factor

$\mathrm{C}_{\mathrm{r}}$-Canopy factor

$\mathrm{C}_{r}$ - Crust correction factor

$\mathrm{S}-\%$ sand 
were implemented, each of which was replicated twice. The treatments were:

1. Clipped-all vegetation was removed at the ground surface and lightly raked to remove loose plant material.

2. Grazed-open to seasonal grazing consistently for 20 years prior to study.

3. Ungrazed - protected from livestock grazing for 10 years prior to study.

Johnson and Blackburn (1989) conducted rainfall simulation on 3 sites: Coyote Butte, Summit and Nancy87. The 1987 Nancy plots were located in close proximity to the 1982 Nancy plots but there were differences in soil texture (Table 1). Three treatments, each replicated twice, were applied to each site.

1. Grazed-vegetation and soil remained undisturbed except for grazing by livestock and wildlife.

2. Clipped-standing vegetation was harvested to ground level by clipping.

3. Bare-standing vegetation was harvested to ground level by clipping; surface litter, rocks, and cryptogams were removed by hand. The only remaining cover was root crowns and fine litter fragments. Although efforts to remove all the litter fragments were painstaking, cover determinations by detailed point framing revealed high amounts of nonpersistent litter on the bare plots at Nancy87 and Summit (Table 1).

Similar rainfall simulation technology and methods were used for both the 1982 and 1987 studies. A rotating boom rainfall simulator (Swanson 1979) was used to simulate rainfall on a plot initially dry (dry run) (60-minute application) and initially at field capacity (wet run) (30-minute application 24 hours after the dry run). A very wet run was also simulated, but the procedure differed for the respective studies. Thirty minutes after the wet run, Johnson et al. (1984) simulated rainfall at a constant intensity for 30 minutes. Johnson and Blackburn (1989) similarly simulated rainfall 30 minutes after the wet run, but maintained a constant intensity for 10 minutes only. Thereafter, they combined different rain intensities with different rates of overland flow. Rainfall intensity was simulated at about $63 \mathrm{~mm} / \mathrm{hr}$ for both studies with the exception of the post 10 -minute period of the very wet run of Johnson and Blackburn (1989).

\section{Model Simulations}

The WEPP hillslope model (version 89) was used to simulate runoff for the dry, wet, and very wet runs of Johnson et al. (1984) and the dry and wet run of Johnson and Blackburn (1989). This version of the WEPP model is not distributed and assumes a homogeneous hillslope. Three different model simulations were performed for each plot. These simulations differed with respect to the estimation of the Green and Ampt parameters, $K_{e}$ and $N_{s}$. For the first simulation, $K_{0}$ and $N_{3}$ were estimated using the empirical parameter estimation techniques described above (eqs. 2-12). For the second simulation, $K_{\mathrm{e}}$ was determined from the field measuremients. $K_{\text {. }}$ was estimated from the final infiltration rate of the very wet run as recommended by Nearing et al. (1989). Na was estimated as before, using the empirical parameter estimation procedure. In the third simulation, $K_{\mathrm{e}}$ was estimated using final infiltration rates

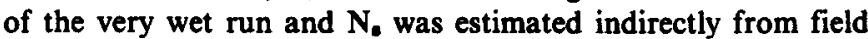
measurements by rearranging the Green and Ampt equations as follows (Nearing et al. 1989).

$$
N_{\mathbf{s}}=\frac{F\left(f-K_{\bullet}\right)}{\left.K_{\bullet}\right)}
$$

$F$ is total infiltration $(\mathrm{mm})$ and $f$ is final infiltration rate $(\mathrm{mm} / \mathrm{hr})$ for the respective dry or wet run. No estimates of $\mathrm{N}_{3}$ were made for the very wet runs because with $f=K_{e}, N_{s}$ would be zero. The above equation (eq. 13) is an appropriate estimate of $N_{\text {s }}$ if the Green and Ampt equation correctly represents infiltration on sagebrush range- land. A direct estimate of $\mathrm{N}_{\mathbf{3}}$ is difficult to make, requiring detailed field and laboratory measurements (Mein and Larson 1973, Brakensiek 1977).

The first simulation is referred to as the "WEPP" simulation, since no model calibration or parameter adjustment was performed to maximize predictability. The second simulation is referred to as the "estimated" simulation, since $\mathbf{K}_{\mathbf{8}}$ was estimated from the field data. The third simulation is called the "computed" simulation, since $N_{*}$ was computed using the data and the Green and Ampt equation. It is important to recognize that the "computed" simulation amounts to calibrating the model, or forcing a best "fit" between observed and predicted runoff. The purpose of

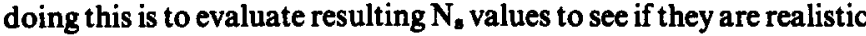
and to assess how well the Green and Ampt equation fits observed infiltration characteristics of sagebrush rangeland.

\section{Model Evaluation}

Model performance was evaluated using the Nash and Sutcliffe (1970) coefficient of efficiency (E). $E$ is computed as follows

$$
E=1-\left[\Sigma\left(Y_{\text {obs }}-Y_{\text {pred }}\right)^{2} / \Sigma\left(Y_{\text {obs }}-Y_{\text {mean }}\right)^{2}\right]
$$

$Y_{\text {obs }}$ is observed runoff, $Y_{\text {prod }}$ is model predicted runoff, and $Y_{\text {mean }}$ is mean observed runoff.

$E$ is the proportion of the variance of the observed values accounted for by the model. Its values can range from 1 to-infinity. A negative value indicates that the observed mean does better predicting $Y_{\text {obs }}$ than does the model.

\section{Results and Discussion}

\section{Runoff Prediction}

A comparison of predicted and observed runoff for each of the 3 simulations ("WEPP", "estimated", and "computed") is given in Figure 1. There was a poor correlation between predicted and observed runoff for both the "WEPP" and "estimated" simulations, as indicated by the scatter in the data and the low coefficient of efficiencies (Figs. 1 and 1b). Runoff predictions for the "computed" simulation as expected, were much improved (Fig. 1c).

An examination of runoff prediction by site is instructive (Table 2). Highest average runoff ("WEPP" simulation) was predicted on Flats, Summit, and Nancy82. In contrast, very little runoff was predicted on Nancy87, Coyote Butte, and Lower Sheep. Average predicted runoff corresponded to observed average runoff only on the Nancy 82 and Lower Sheep sites. Runoff prediction is heavily dependent on the final estimate of hydraulic conductivity, $K_{e}$, given in eq. 5 . This is where the effect of vegetal cover, surface crusting, and macroporosity to hydraulic conductivity are taken into account. The macroporosity factor, $M_{f},(e q .7)$ is especially important. It can range in value from 0.4 for sandy soils to over 40 for clayey soils. If $\mathbf{M}_{f}<1$, then vegetal cover has relatively little impact on hydraulic conductivity. For soils with a high $\mathbf{M}_{\mathbf{f}}$, the effect of vegetation on hydraulic conductivity can be enormous. Significant runoff was predicted only from those sites with low $M_{f}$ : Summit, Flats, and Nancy82 (Tables 1 and 2). On these sites, because of the low $M_{\mathrm{f}}$, the changes in vegetal cover associated with the different treatments had little impact on $K_{e}$ and therefore on runoff. Little or no runoff was predicted from those sites with very high estimates of $M_{f}\left(\right.$ Nancy 87 and Coyote Butte). The canopy $\left(C_{f}\right)$ and crust $\left(C_{r}\right)$ factors, in comparison to $M_{f}$, were much less variable between sites and had relatively little impact on runoff prediction (Table 1).

When measured values of $K_{e}$ were used ("estimated" simulation), runoff was consistently underestimated (Table 2). Predictions, as one might expect, were much better after $\mathrm{N}_{\text {. was estimated }}$ by back calculating from the Green and Ampt equation using observed values for $f, F$, and $K_{e}$ ("computed" simulation). The 
A.

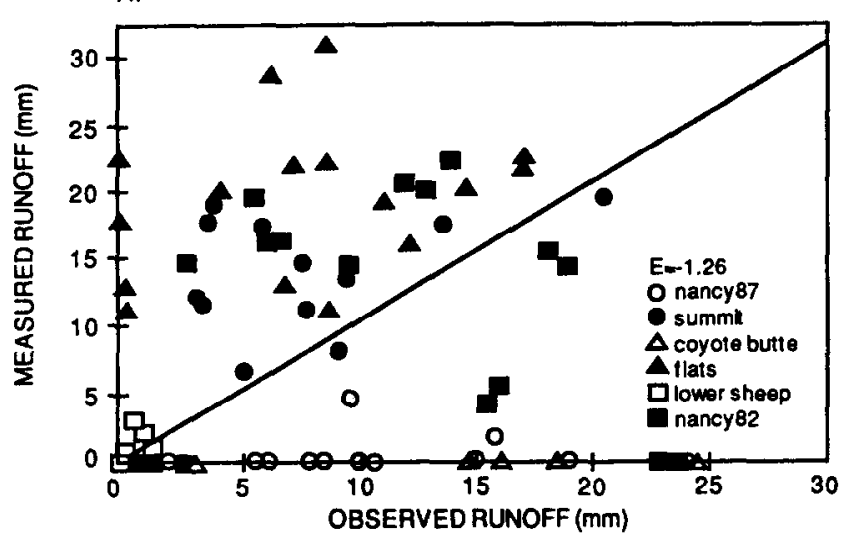

B.

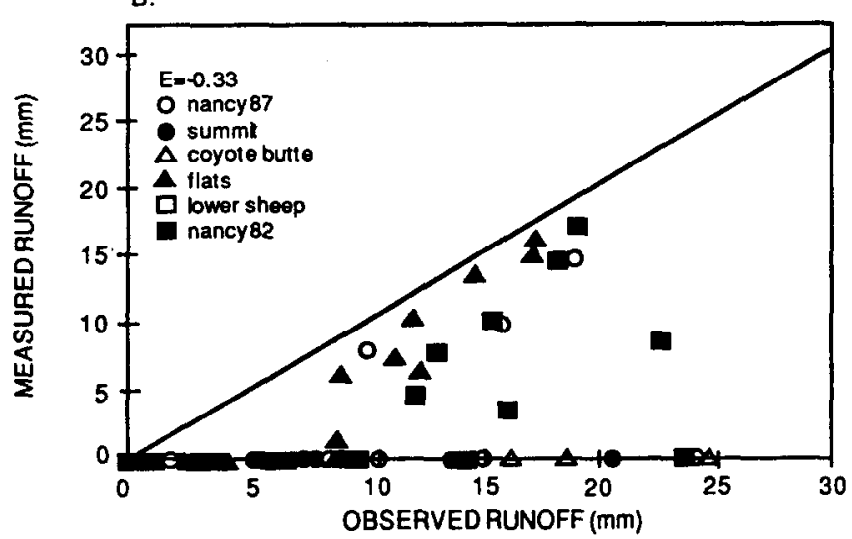

C.

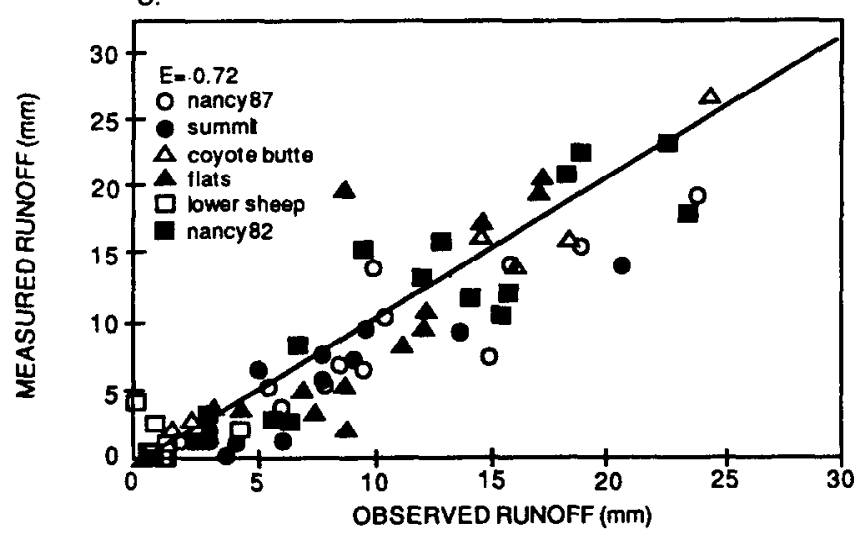

Fig. 1. Comparison of predicted and observed runoff for the (a) "WEPP" simulation (b) "cstimated"simulation and (c) "computed" simulation. In the "WEPP" simulation, $K$ and $N$ were computed by empirical relationships. In the "estimated" simulation $\mathrm{K}_{\text {, was }}$ estimated as final infiltration rate of the very wet run and $N_{\text {, was }}$ empirically estimated. In the "computed" simulation both $\mathrm{K}_{\mathrm{s}}$ and $\mathrm{N}_{\mathrm{s}}$ were estimated from the field experiments.

"computed" simulation amounts to a calibration of the model rather than a validation, but the relatively good fit indicates that the Green and Ampt equation can describe infiltration on sagebrush rangeland. We will examine later whether the values of $N_{\text {. }}$ estimated in this fashion are realistic.

In general, measured runoff increased with the degree of vegetation removed (Table 2) (see Johnson et al. 1984 and Johnson and Blackburn (1989) for more detailed discussion of treatment effects). The "WEPP" simulations did not reflect these treatment effects (Table 2). Probable reasons for this are that ground cover (rocks, cryptogams, root crowns, nonpersistent litter) was high for
Table 2. Average runoff $(\mathrm{mm})$ for each site and treatment within sites, that was predicted by WEPP and observed in the field. Runoff was predieted using the 3 different procedures for estimating the Green and Ampt infiltration parameters as discussed in the text.

\begin{tabular}{lcccc}
\hline \hline Site & WEPP & Est. & Computed & Obs. \\
\hline Nancy87 & $\cdots .5$ & 2.7 & 0.9 & 11.1 \\
Grazed & 0 & 0 & 5.7 & 6.6 \\
Clipped & 0 & 2.4 & 9.5 & 10.7 \\
Bare & 1.5 & 5.6 & 11.4 & 16.1 \\
Summit & 14.0 & 0 & 5.5 & 7.8 \\
Grazed & 13.9 & 0 & 5.7 & 8.1 \\
Clipped & 15.1 & 0 & 1.4 & 3.6 \\
Bare & 12.9 & 0 & 9.4 & 11.8 \\
Coyote Butte & 0 & 0 & 6.8 & 6.9 \\
Grazed & 0 & 0 & 1.6 & 1.4 \\
Clipped & 0 & 0 & 0.6 & 1.0 \\
Bare & 0 & 0 & 18.2 & 18.5 \\
Flats & 20.7 & 4.2 & 7.2 & 7.7 \\
Ungrazed & 20.9 & 0 & 0.7 & 1.3 \\
Grazed & 17.5 & 3.6 & 9.8 & 9.8 \\
Clipped & 23.9 & 9.1 & 11.0 & 12.2 \\
Lower Sheep & 0.8 & 0 & 0.7 & 0.5 \\
Ungrazed & 0 & 0 & 0 & 0 \\
Grazed & 0.6 & 0 & 1.7 & 0.6 \\
Clipped & 0.5 & 0 & 0.5 & 0.7 \\
Nancy82 & 10.1 & 3.6 & 10.0 & 10.6 \\
Ungrazed & 5.1 & 0 & 2.4 & 2.4 \\
Grazed & 18.7 & 2.0 & 10.1 & 10.1 \\
Clipped & 6.5 & 8.7 & 17.5 & 19.2 \\
\hline WEP- & & 0 & & \\
\hline
\end{tabular}

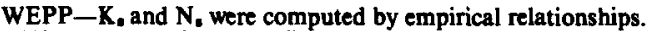

EST.- $K$, was estimated as final infiltration rate of very wet run and $N_{\text {a }}$ was computed using an empirical relationship.

COMPUTED - K, was estimated as final infiltration rate of very wet run and N, was estimated by back calculating from the Green and Ampt equation.

OBS.-Observed runoff.

all of the treatments (Table 1). Ground cover can greatly increase the WEPP estimate of hydraulic conductivity. By comparison, WEPP is relatively insensitive to canopy cover.

Simulated treatment effects were more pronounced when $K_{\text {e }}$ ("estimated" simulation) and $\mathrm{K}_{e}$ and $\mathrm{N}_{\mathrm{s}}$ ("computed" simulation) were estimated from field measurements (Table 2).

\section{Parameter Estimation}

On average, predicted $K_{e}$ was lower than $K_{e}$ measured by about $13 \mathrm{~mm} / \mathrm{hr}$ (Table 3). The coefficient of efficiency was negative ( $\mathrm{E}=$ -0.44 ), indicating a poor correlation between predicted and the measured $K_{e}$. Best predictions of $K_{e}$ were at Nancy87 and Coyote Butte; runoff at these sites was underpredicted, however, (Table 2). Runoff prediction was much better on the sites where $K_{\boldsymbol{*}}$ was poorly estimated, such at Summit and Nancy82. In other words, ablity of the model to accurately predict $K_{\mathbf{e}}$ did not insure accurate runoff prediction. The reverse also holds true: accurate runoff prediction does not necessarily imply that the parameters were accurately estimated. There was little variation between predicted $\mathrm{K}_{\mathrm{e}}$ within the different treatments. This is mainly a reflection of the fact that different treatments were imposed on different sites. Within sites, predicted $K_{e}$ did differ with treatment, if $M_{\mathbf{f}}$ was greater than 1.

The results of this study highlight the importance of $\mathbf{M}_{\mathbf{f}}$, the macroporisty factor, for predicting $K_{\mathbf{e}}$. If $\mathbf{M}_{\boldsymbol{r}}<1$, then vegetation change will have no effect. $A$ high $\mathbf{M}_{\mathrm{f}}$ will also cause the predicted runoff to be relatively insensitive to vegetation change. This is because $K_{e}$ will always be high enough to insure that predicted runoff is small, unless ground cover is zero. A case in point is 
Table 3. Average effective hydraulic conductivity ( $\mathrm{mm} / \mathrm{hr}$ ) computed by WEPP (Predicted $\mathrm{K}_{\mathrm{e}}$ ) and measured hydraulic conductivity (Measured $K_{e}$ ) averaged across all plots (total), individual sites and treatments. Also included are the number of plots (\#) used in each calculation*.

\begin{tabular}{|c|c|c|c|}
\hline \multirow[b]{3}{*}{ Site/Trt. } & \multicolumn{2}{|c|}{ Average Effective Hydrualic } & \multirow[b]{3}{*}{$\#$} \\
\hline & Conductivity & & \\
\hline & Predicted $\mathrm{K}$. & Measured $\mathrm{K}_{\text {. }}$ & \\
\hline Total & $\begin{array}{c}(\mathrm{mm} / \mathrm{hr}) \\
20\end{array}$ & $\underset{33}{(\mathrm{~mm} / \mathrm{hr})}$ & 36 \\
\hline $\begin{array}{l}\text { Nancy87 } \\
\text { Summit } \\
\text { Coyote Butte } \\
\text { Flats } \\
\text { Lower Sheep } \\
\text { Nancy82 }\end{array}$ & $\begin{array}{r}18 \\
14 \\
39 \\
8 \\
31 \\
13\end{array}$ & $\begin{array}{l}18 \\
33 \\
40 \\
28 \\
54 \\
30\end{array}$ & $\begin{array}{l}6 \\
6 \\
6 \\
6 \\
6 \\
6\end{array}$ \\
\hline $\begin{array}{l}\text { Ungrazed } \\
\text { Grazed } \\
\text { Clipped } \\
\text { Bare }\end{array}$ & $\begin{array}{ll} & \text { Trea } \\
18 & \\
22 & \\
22 & \\
18 & \end{array}$ & $\begin{array}{l}49 \\
35 \\
32 \\
20\end{array}$ & $\begin{array}{r}6 \\
12 \\
12 \\
6\end{array}$ \\
\hline
\end{tabular}

* Measured $\mathrm{K}_{\mathrm{e}}$ was computed as the very wet run final infiltration rate.

Coyote Butte, where no runoff was predicted (Table 2). Although this term is called the macroporosity factor it has no physical basis; rather it is an empirical adjustment factor. The model developers assumed that rangeland soils have a better developed network of macropores than agricultural soils, thus higher infiltration capacities (D.L. Brakensiek, personal communication).

Historically, more effort has been devoted to the development of a procedure for predicting $\mathrm{K}_{\mathrm{e}}$ than for $\mathrm{N}_{\mathrm{s}}$. The rationale is that $\mathrm{K}_{\mathrm{e}}$ is the more sensitive of the 2 parameters (Brakensiek and Onstad 1977 ), and $N_{B}$ is assumed to be relatively unaffected by soil surface changes (Rawls et al. 1989a). Adequate prediction of $K_{e}$ alone however, does not insure accurate runoff predictions, as demonstrated by the inability of the model to accurately predict runoff when measured values of $K_{\bullet}$ were used ("estimated" run) (Fig. lb). $\mathrm{N}_{\mathrm{s}}$ must be accurately predicted as well. Our results suggest that this may be a difficult problem.

$N_{\mathrm{a}}$ is affected by average matric potential across the wetting front $\left(\mathbf{S}_{\mathrm{f}}\right)$, antecedent soil water, and soil porosity (eq. 11). In Table 4 , we compared by site, predicted $S_{f}$ and fitted $S_{f}$ (computed from field data through back calculation of the Green and Ampt equation and accounting for the effects of soil water and soil porosity). The sites are grouped by textural class. In general, there was a poor

Table 4. Average $S_{f}$ predicted by the empirical parameter estimation techniques (Predicted $S_{f}$ ) and average $S_{f}$ estimated from back calculations of the Green and Amp equation (Fitted $S_{f}$ ) for all of the plots (total) and individual sites. Also included are the number of plots (\#) used in each calculation*, and the textural class of the soil for each site.

\begin{tabular}{lccrll}
\hline \hline & \multicolumn{2}{c}{ Average $\mathbf{S}_{\mathrm{f}}$} & & \\
\cline { 2 - 3 } Site & Predicted S/f & Fitted S/f & $\#$ & Soil Texture \\
\hline Total & 230 & 105 & 61 & \\
Coyote Butte & 480 & 44 & 10 & silt loam \\
Nancy87 & 294 & 203 & 12 & silt loam \\
Lower Sheep & 207 & 7 & 5 & loam \\
Nancy82 & 181 & 72 & 12 & loam \\
Flats & 141 & 174 & 10 & sandy loam \\
Summit & 90 & 72 & 12 & loamy sand \\
\hline
\end{tabular}

*Calculations were based upon dry and wet run rainfall simulations. If no runoff was recorded the plot was excluded from the calculation. match between fitted and predicted $S_{f}$. Average fitted $S_{f}$ was considerably lower than predicted $S_{f}$, especially at Coyote Butte and Lower Sheep.

There was no clear relationship between fitted $S_{f}$ and soil texture (Table 4). In other words soil texture may not be a reliable predictor of $S_{f}$. This needs to be evaluated on more sites. Although McCuen et al. (1981) have shown that $S_{f}$ varies collectively across soil textural class, their data also show that $S_{f}$ can vary considerably within a particular textural class. Our predictions of $S_{f}$, of course, are based upon the assumption that the Green and Ampt equation adequately describes infiltration for sagebrush rangelands. One criterion is a good fit for the "calibrated" run, where fitted $N_{s}$ values were used. The other criterion is that when $N_{s}$ is computed from the Green and Ampt equation, values be realistic. Fitted $S_{f}$ values were low on all of the sites; however, they were, with the exception of Lower Sheep, within the range of values for each texture class reported by McCuen et al. (1981). At Lower Sheep, the small amount of runoff precluded a good estimate of $S_{f}$. These results, plus the good fit by the computed model, indicate that the Green and Ampt equation does a reasonable job of describing infiltration on sagebrush rangelands.

\section{Model Assessment}

We have attempted a realistic evaluation of runoff prediction by WEPP, when the parameter estimation techniques are used. No attempt has been made to display the model in a "best light". Results, however, should be placed in the context of current stateof-the-art in rainfall-runoff modeling. There is a great deal of uncertainty associated with hydrologic predictions, even by the most sophisticated models (Beven 1987). It is unrealistic to expect an uncalibrated rainfall runoff model to precisely predict runoff (Wilcox et al. 1989a, b; Wilcox et al. 1990; Wilcox et al. 1991). Rainfall-runoff models are typically parameterized by calibrating or "fitting" the model to an observed runoff record. This requirement greatly limits model application for many rangeland watersheds, where runoff records are limited. It also provided the impetus for development of the parameterization techniques evaluated here. These techniques are a new and necessary approach for model parameterization, but they are first cut. Improvements need to be made, but the challenge is great. The highly empirical nature of the parameterization techniques is an obvious problem, see for exmple equation 12. Brakensiek and Rawls (1992) are exploring fractal mathematics as a way of relating $K_{s}$ to soil texture in a less empirical fashion.

The spatial variability found on rangelands is a major limitation. The infiltration capacity on sagebrush rangelands, for example, is extremely variable from shrub to interspace (Blackburn 1975). This kind of spatial variability is not accounted for in WEPP, which is not a distributed model. Even distributed models cannot, without great difficulty, incorporate such small scale variability.

There is also large variability between different rangeland types. The approach taken by the WEPP model developers has been to develop empirical relationships that can be applied to all rangelands. It may be that more site or location specific relationships need to be developed. This variability might be accounted for with the development of different parameter estimation procedures for each major rangeland type.

Our results are in basic agreement with earlier assessments of runoff prediction by WEPP. Rawls and Brakensiek (1988), demonstrated the relative imprecision of the WEPP infiltration component on rangelands, but were pleased that model predictions were within one standard deviation of observed infiltration. Wilcox et al. (1990) compared the Green and Ampt approach to the curve number method for predicting average annual and monthly runoff on 6 diverse rangeland watershed, and found poorest predictions by both models on sagebrush rangeland. 


\section{Conclusions}

The key to improving runoff prediction by WEPP is the improvement of the parameter estimation procedures. Considering the spatial variability of rangelands, this is a formidable task. One possibility is the development of specific procedures for the major rangeland plant communities. It is doubtful that empirical relationships could be developed that are universally applicable for all rangelands.

The macroporosity factor has a large impact on the relative effect of vegetation on infiltration and runoff and needs to be further investigated-specifically, the relationship between soil texture and the runoff response to vegetation change. As currently written, infiltration characteristics of sandy soils are relatively unresponsive to vegetation change and infiltration rates of high clay soils are extremely responsive to vegetation change. Is this consistent with field observation? The relationship between soil texture and the matric potential at the wetting front also needs further investigation. Our results suggest that soil texture is a poor indicator of $\mathrm{N}_{\mathrm{s}}$.

Results indicate the need for continued improvement in the Green and Ampt parameterization procedures. The model as it currently stands may be adequate for predicting average runoff conditions but lacks the ability to predict runoff differences due to differences in vegetation or soil characteristics. These results are merely a reflection of our own incomplete understanding and limited ability to quantify vegetation, soil, and hydrologic interactions on rangelands. This limits our ability to evaluate the impact of land use on rangelands, but does represent an exciting research frontier in rangeland hydrology.

As pointed out by Nearing et al. (1991) poor model performance at 1 location does not necessitate modification of the model. Validation studies like this need to be carried out for many range sites so that consistent model deficiencies may be identified and model improvements made.

\section{Literature Cited}

Beven, K. 1987. Towards a new paradigm in hydrology. Int. Assoc. of Sci. Hydrology Pub. 164:393-403.

Blackburn, W.H. 1975. Factors influencing infiltration and sediment production on semiarid rangelands in Nevada. Water Resour. Res. 11:929-937.

Brakensiek, D.L. 1977. Estimating the effective capillary pressure in the Green and Ampt infiltration equation. Water Resour. Res. 13:680-682.

Brakensiek, D.L., and C.A. Onstad. 1977. Parameter estimation of the Green and Ampt infiltration equation. Water Resour. Res. 13:1009-1012.

Brakensiek, D.L., and W.J. Rawls. 1983. Agricultural management effects on soil water processes, Part II, Green and Ampt parameters for crusting soils. Trans. Amer. Soc. Agr. Eng. 26:1753-1757.

Brakensiek, D.L., and W.J. Rawls. 1992. Using the Sierpinski carpet algorithm to calculate saturated conductivity. Water Resour. Res. (In Press).
Chu, S.T. 1978. Infiltration during an unsteady rain. Water Resour. Res. 14:461-466.

Johnson, C.W., and Blackburn. 1989. Factors contributing to sagebrush rangeland soil loss. Trans. Amer. Soc. Agr. Eng. 32:155-160.

Johnson, C.W., M.R. Savabi, and S.A. Loomis. 1984. Rangeland erosion measurements for the USLE. Trans. Amer. Soc. Agr. Eng. 27:1313-1320.

Lane, L.J., and M.A. Nearing (eds.). 1982. USDA-Water Erosion Prediction Project: Hillslope Profile Version. NSERL Rep. 2, National Soil Erosion Research Laboratory, USDA-ARS, W. Lafayette, Ind. 253 p.

McCuen, R.H., W.J. Rawl, and D.L. Brakensiek. 1981. Statistical analysis of the Brooks-Corey and the Green-Ampt parameters across soil textures. Water Resour. Res. 17:1005-1013.

Mein, R.G., and C.C. Larson. 1971. Modeling the infiltration component of the rainfall-runoff process. Bull. 43, Water Resour. Res. Center, Univ. Minnesota, Minn.

Mein, R.G., and C.C. Larson. 1973. Modeling infiltration during a steady rain. Water Resour. Res. 9:384-394.

Nash, J.E., and J.V.Sutcliffe. 1970. River flow forecasting through conceptual models, 1, A discussion of principles. J. Hydrol. 10:282-290.

Nearing, M.A., L.J. Lane, E.E. Alberts, and J.M. Laflen. 1991. Prediction technology for soil erosion by water: status and research needs. Soil Sci. Soc. Amer. J. 54:1702-1711.

Nearing, M.A., M.A. Weltz, S.C. Finkner, J.J. Stone, and L.T. West. 1989. Parameter identification from plot data. p. 11.1-11.15. In: L.J. Lane and M.A. Nearing (eds.), USDA-Water Erosion Prediction Project: Hillslope Profile Version. NSERL Rep. 2, Nat. Soil Erosion Res. Lab., USDA-ARS, W. Lafayette, Ind.

Rawls, W.J., and D.L. Brakensiek. 1985. Prediction of soil water properties for hydrologic modeling, Proc. Amer. Soc. Civil Eng. Watershed Management in the Eighties Symposium, Denver, Colo. p. 293-299.

Rawls, W.J., and D.L. Brakensiek. 1988. An infiltration model for evaluation of agricultural and rangeland management systems. p. 166-175. In Modeling Agricultural Forest, and Rangeland Hydrology, Proc. Int. Symp., Amer. Soc. Agr. Eng., Chicago, Ill.

Rawls, W.J., D.L. Brakensiek, and R. Savabi. 1989a. Infiltration parameters for rangeland soils. J. Range Manage. 42:139-142.

Rawls, W.J., J.J. Stone, and D.L. Brakensiek. 1989b. Infiltration. p. 4.1-4.11. In: L.J, Lane and M.A. Nearing (eds.), USDA-Water Erosion Prediction Project: Hillslope Profile Version. NSERL Rep. 2, Nat. Soil Erosion Res. Lab., USDA-ARS, W. Lafayette, Ind.

Smith, R.E., and J.Y. Parlange. 1978. A parameter-efficient hydrologic infiltration model. Water Resour. Res. 14:533-538.

Swanson, N.P. 1979. Field plot rainfall simulation (rotating-boom rainfall simulator) Lincoln, Nebraska. p. 167-169. In: Proc. Rainfall Simulator Workshop, Tucson, Arizona, USDA-SEA Agr. Reviews and Manuals, ARM-W-10.

Wilcox, B.P., K.R. Cooley, and C.L. Hanson. 1989a. Predicting snowmelt runoff on sagebrush rangeland using a calibrated SPUR hydrology model. Trans. Amer. Soc. Agr. Eng. 32:1351-1357.

Wilcox, B.P., C.L. Hanson, J.R. Wight, and W.H. Blackburn. 1989b. Sagebrush rangeland hydrology and evaluation of the SPUR model. Water Resour. Bull. 25:653-666.

Wilcox, B.P., M.S.Seyfried, K.R. Cooley, and C.L. Hanson. 1991. Runoff characteristics of sagebrush rangelands: modeling implications. J. Soil and Water Conserv. 46:153-158.

Wilcox, B.P., W.J. Rawls, D.L. Brakensiek, and J.R. Wight. 1990. Predicting runoff from rangeland catchments: a comparison of two models. Water Resour. Res. 26:2401-2410. 